\title{
Reading Geography and Geographers and Political Geography today
}

\author{
Katharine Hall
}

Published online: 7 May 2020

(C) The Author(s) 2020

\begin{abstract}
This reflection focuses on reading Geography and Geographers and Political Geography today. In particular, it examines these texts in relation to the contexts of the changing nature and structure of the university and the persistence of white supremacy and anti-black violence in our contemporary moment. In doing so, I look at how these texts might better include some of these challenges-to consider the increasing precarity of the academic job market and to better incorporate black geographies as foundational to the field.
\end{abstract}

Keywords Higher education, Political geography · Graduate school · Black geographies

I had the opportunity to read these two texts for the first time for the conference panel leading to this set of papers. They each provide an introduction to a discipline or subdiscipline-human geography and political geography-largely aimed at undergraduate and graduate students. Both of these texts have been built over iterations and an especially interesting part of reading them together is seeing how they have

K. Hall $(\bowtie)$

School of Politics and International Relations, Queen

Mary University of London, Mile End Road,

London E1 4NS, UK

e-mail: k.hall@qmul.ac.uk changed, both topically and in approach, over time. My commentary focuses on reading them today, however, situating them within structures of higher education and our contemporary political climate. In particular I want to think about reading them in connection to two key issues: first, the shifting structure of the university and increased precaritysomething that is felt especially by early career scholars-and second, white supremacy, fascism and anti-black violence. Both of these issues shape our contemporary world and our academic environment and workplace.

One of the things I found especially appealing about Geography and Geographers is that it starts not with the foundations of the field of human geography (that is the subject of the second chapter) but rather with an overview and description of the academy and the university. This helps frame the ins and outs of the stories of the disciplinary shifts that follow. For example, and something I have had a crash course in over the last year, the UK and US university systems have significant differences. Sidaway and Johnston lay this out in a very clear manner and it helps us to understand later how certain areas of geography (for example, political geography) have developed more and in certain ways in one country and not the other.

But beginning with the structure of an academic discipline also serves as a useful guide for $\mathrm{PhD}$ students interested in pursuing an academic career. And here the book provides a good starting point, especially about the structure of the academy and 
career progression. It doesn't focus however on some key factors that are producing radical changes in the academy. Simply put, not only are there are not enough academic jobs but the jobs that do exists are increasingly temporary and precarious ones-it is really hard to get on that ladder they describe in the textbook. In the US this often means working with no benefits and/or working at multiple institutions to piece together enough salary, and in the UK this often means short contracts with high teaching hours. Both involve frequent movement, which is not only detrimental to research but also to the possibility of family and well-being in general. As universities in both countries move toward more temporary contracts this problem grows, and faculty of colour and women are impacted the most by these changes.

Geographers, however, have been studying these changes and pushing back on them, and this scholarship and activism needs to be accounted for as part of the emerging directions of the discipline. One of the most visible examples to me last year was the University and College Union (UCU) strike to protect pensions-I was one of the many who followed this remotely on Twitter from the US. The strikes happened across disciplines in the UK but also raised questions about geography and the narration of the history of critical geography. As Felicity Callard wrote in her piece "\#notallgeographers," “...tensions today have not been solely about which geographers areand are not - on the picket lines. Broader issues over where the discipline of geography is made, and who comes to represent that discipline are at stake. On the picket lines and on social media, geography's present and past—both in material and fantasmatic form-are being worked up and worked through." (Callard 2018) I think that future editions of this textbook are going to have to contend with these economic and structural changes and the impacts they are having on the development of the discipline.

A perhaps more noticeable absence from Geography and Geographers and Political Geography is a sustained discussion about race. In the latter, the topic crops up in the consideration of European empires. In the former, the engagement with the topic is largely in a section called 'Race,' racisms and ethnocentrism' in the chapter on 'Postmodernism, Poststructuralism, Postcolonialism.' This section provides a short review of work on racism, a bit on white supremacy and identity, and some cursory questions about the whiteness of the discipline. However, there is no sustained discussion about black geographies or reference to the key scholars shaping this field. This is at best a missed opportunity and at worst an active exclusion of one of the most important developments in the discipline.

It is not clear why the authors do not engage with this part of the discipline. Two of the most glaring absences are the works of Ruth Wilson Gilmore and Katherine McKittrick. Golden Gulag (Gilmore 2007) and Demonic Grounds (McKittrick 2006) are foundational texts of human geography_radically reshaping concepts in the discipline but also moulding an expanding cohort of graduate students and $\mathrm{PhD}$ projects. The AAG also recently created (however belatedly) a black geographies specialty group, and the question of whiteness of the discipline has been an ongoing topic addressed by AAG presidents in their newsletters over the last few years (Domosh 2015; Alderman and Tyner 2018). Much attention is given in the textbook to similar shifts and development-and it seems perhaps that a chapter on feminist geography came about in this way. Note, however, that Kim England (Boyle et al. 2017) raised a similar absence of black feminist geography in this chapter. Camilla Hawthorne (2019) has recently published a review of black geographies in Geography Compass and this might be a good starting point for thinking about how these developments intersect with the ones described in Geography and Geographers (see also Hawthorne and Meché 2016; Bledsoe and Wright 2019). Engaging with this scholarship more directly is important not only for providing a more complete picture of the discipline but also for preparing scholars to better address issues of white supremacy and anti-black violence in the classroom and in the university.

Open Access This article is licensed under a Creative Commons Attribution 4.0 International License, which permits use, sharing, adaptation, distribution and reproduction in any medium or format, as long as you give appropriate credit to the original author(s) and the source, provide a link to the Creative Commons licence, and indicate if changes were made. The images or other third party material in this article are included in the article's Creative Commons licence, unless indicated otherwise in a credit line to the material. If material is not included in the article's Creative Commons licence and your intended use is not permitted by statutory regulation or exceeds the permitted use, you will need to obtain permission directly from the copyright holder. To view a copy of this licence, visit http://creativecommons.org/licenses/by/4.0/. 


\section{References}

Alderman, D., \& Tyner, J. (2018). Non-killing geographies. AAG Newsletter. Retrieved 30 December 2019, from https://news.aag.org/2018/02/non-killing-geographies/.

Bledsoe, A., \& Wright, W. J. (2019). The pluralities of black geographies. Antipode, 51(2), 419-437.

Boyle, M., England, K., Farish, M., Beaten, G., Gilmartin, M., De Vivo, M. S., et al. (2017). Geography and geographers: Anglo-American human geography since 1945, 7th edn. AAG Review of Books, 5(1), 48-61.

Callard, F. (2018). \#notallgeographers. HHS blog post. History of the Human Sciences. Retrieved 30 December 2019, from https://www.histhum.com/notallgeographers/.

Domosh, M. (2015). Why is our geography curriculum so white? AAG Newsletter. Retrieved 30 December 2019, from https://news.aag.org/2015/06/why-is-our-geographycurriculum-so-white/.
Gilmore, R. W. (2007). Golden gulag: Prisons, surplus, crisis, and opposition in globalizing California. Berkeley: University of California Press.

Hawthorne, C. (2019). Black matters are spatial matters: Black geographies for the twenty-first century. Geography Compass, 13(11), e12468. https://doi.org/10.1111/gec3. 12468.

Hawthorne, C., \& Meché, B. (2016). Making room for black feminist praxis in geography. Society and space online. Retrieved 30 December 2019, from https:// societyandspace.org/2016/09/30/making-room-for-blackfeminist-praxis-in-geography/.

McKittrick, K. (2006). Demonic grounds: Black women and the cartographies of struggle. Minneapolis: University of Minnesota Press.

Publisher's Note Springer Nature remains neutral with regard to jurisdictional claims in published maps and institutional affiliations. 